\title{
Socioeconomic factors and mortality in urban settings: the case of Barcelona, Spain
}

\author{
Carme Borrell, Antoni Arias
}

\begin{abstract}
Study objective - This study aimed to describe the relationship between health and socioeconomic indicators in the 38 neighbourhoods of the city of Barcelona, Spain. Design - Mortality data for 1983-89 and socioeconomic data for each of the 38 neighbourhoods of Barcelona were used. Mortality indicators used were the comparative mortality figure, the ratio of potential years of life lost, and life expectancy at birth. Socioeconomic indicators were the percentage of unemployed, the percentage of illiteracy, monthly telephone usage, the average power and age of cars, and the average rateable value of buildings and of land. The statistical correlation between socioeconomic indicators and mortality indicators was studied by Spearman's rank correlation coefficient.
\end{abstract}

Setting - The 38 neighbourhoods of Barcelona, Spain.

Measurements and main results - The comparative mortality figure ranged from $87 \cdot 41-152 \cdot 43$ and the ratio of potential years of life lost from 74.94-237.31 in both sexes. Both the absolute difference and the ratio of the value for the neighbourhood with lowest mortality and that with highest mortality were larger when premature mortality was examined. Life expectancy at birth ranged from $64 \cdot 77-75 \cdot 32$ years in men and 75.04-81.51 in women. All correlations between mortality and socioeconomic indicators were high and statistically significant: the higher the unemployment and illiteracy levels and the older the cars, the greater the comparative mortality figure and ratio of potential years of life lost, and the lower the life expectancy (negative correlations). Conversely, the higher the telephone use, the more powerful the cars, and the greater the rateable value, the lower the mortality (negative correlations) and the greater the life expectancy. These correlations were greater in males than in females. The highest correlations were with illiteracy.

Conclusions - This study has detected significant differences in mortality in a large town in the Mediterranean region of Europe.

(f Epidemiol Community Health 1995;49:460-465)

Health, P1 Lesseps 1, 08023 Barcelona,

Spain

C Borrell

A Arias

Correspondence to Dr Borrell

Accepted for publication March 1995
Health inequalities have been the object of considerable interest since the Report of the Resource Allocation Working Party in $1976^{1}$ and the Black report, ${ }^{2}$ both published in the UK. This continued interest in monitoring health inequalities can be explained by the fact that despite improvements in general health indicators at population level, significant differentials continue to be observed in geographical areas and population subgroups. ${ }^{3-6}$ Some recent studies have shown that these differentials, instead of decreasing, are actually widening, ${ }^{7}$ and as a result of this the first aim set by the WHO Health for All strategy was a reduction in health inequalities. ${ }^{8}$

Health inequalities have generally been looked at from two different perspectives. The first, ecological perspective, studies the distribution of population data aggregated by geographical areas. This is the approach that we have used here. The second method considers differences between population groups on the basis of individual data, obtained mainly from mortality data and population surveys, defined by some classification of social status. ${ }^{910}$

The relationship between social factors and health in ecological studies has mainly been established by using unemployment data and proxy indicators for income. ${ }^{56}$ The present study also looks at the relationship between the level of education and health.

Most published ecological studies on the relationship between social factors and health have used small geographical divisions of countries or regions in which social heterogeneity is assumed. There have been fewer studies of geographical divisions of urban and metropolitan areas. It has become clear that cities are urban nuclei with considerable social heterogeneity. They contain pockets of serious poverty or very substandard living conditions that are associated with disease and substandard levels of health. ${ }^{11-13}$ Published research on health inequalities in urban settings has mainly focussed in northern and central European cities. Since patterns of social support and access to health care may differ between the north and the south of Europe, the social indicators related to health may also be dissimilar, the relationship between social and health indicators may vary in size and explanations for these may be different too. ${ }^{14}$ The present study was carried out in an urban setting located in the Mediterranean region of Europe.

This study aimed to describe the relationship between health indicators (life expectancy, overall, and premature death rates) and socioeconomic indicators (unemployment, illiteracy, and proxy indicators for income) using mortality data for 1983-89, in the 38 neighbourhoods of the city of Barcelona, Spain. 


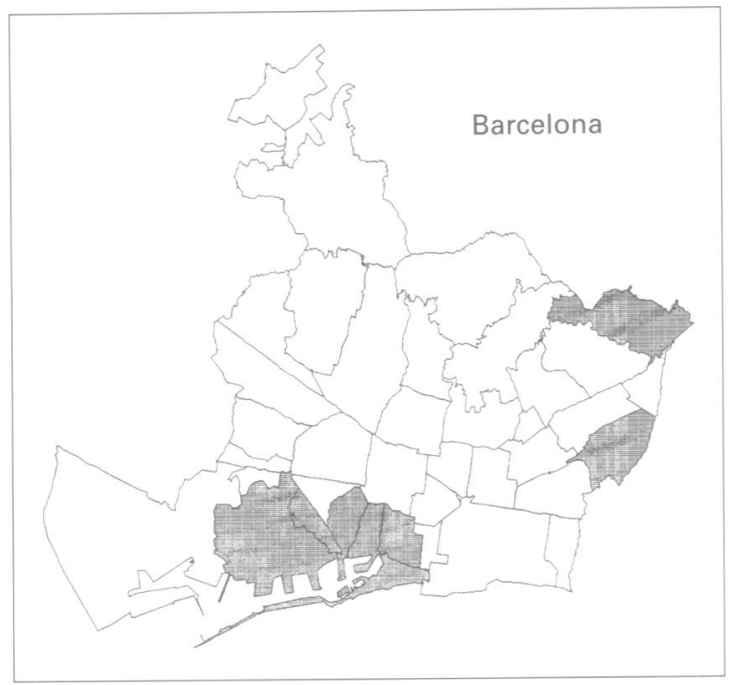

Plan of Barcelona, with the boundaries of the 38 neighbourhoods. The shaded area shows neighbourhoods where both socioeconomic and mortality indicators indicate most disadvantage.

\section{Methods}

Barcelona is a city of 1701812 inhabitants located on the north east coast of Spain. The city is divided into 10 municipal, administrative districts, each made up of various historical neighbourhoods. The figure is a map of Barcelona showing its division into 38 neighbourhoods. The areas examined in this study are these neighbourhoods, which have populations ranging from 1715-113900.

A summary of socioeconomic and mortality indicators is given in table 1 . The data for socioeconomic indicators are taken from the municipal census of $1986,{ }^{15}$ the motor vehicle census of 1987, the rating survey carried out in 1988 , and telephone company data for $1989 .{ }^{16}$

MORTALITY DATA

Mortality data for 1983-9 were obtained from death certificates. Deaths during this period

Table 1 Socioeconomic and mortality indicators used in this study

\begin{tabular}{|c|c|c|c|c|}
\hline & Source & Year & Sex & Unit of measure \\
\hline \multirow{8}{*}{$\begin{array}{l}\text { Socioeconomic indicators: } \\
\text { Unemployment in the active } \\
\text { population aged 15-64 y } \\
\text { Illiteracy in the population } \\
\text { aged 15-64 y } \\
\text { Monthly telephone usage } \\
\text { weighted by the no of } \\
\text { families in neighbourhood } \\
\text { Average power of cars } \\
\text { weighted by the no of } \\
\text { families in neighbourhood } \\
\text { Average age of cars weighted } \\
\text { by the no of families in } \\
\text { neighbourhood } \\
\text { Average rateable value of } \\
\text { buildings and services } \\
\text { (including residential and } \\
\text { commercial) weighted by } \\
\text { the no of families in } \\
\text { neighbourhood } \\
\text { Average rateable value of } \\
\text { land weighted by the no of } \\
\text { families in neighbourhood }\end{array}$} & & & & \\
\hline & Municipal census & 1986 & $\mathrm{M}, \mathrm{F}, \mathrm{T}$ & $\%$ \\
\hline & Municipal census & 1986 & $\mathrm{M}, \mathrm{F}, \mathrm{T}$ & $\%$ \\
\hline & $\begin{array}{l}\text { Telefónica } \\
\text { España SA }\end{array}$ & 1989 & - & Pesetas/mth \\
\hline & Vehicle census & 1987 & - & $\begin{array}{l}\text { Fiscal horse power } \\
\text { (cc) }\end{array}$ \\
\hline & Vehicle census & 1987 & - & Years \\
\hline & Rating survey & 1988 & - & Millions of pesetas \\
\hline & Rating survey & 1988 & - & Millions of pesetas \\
\hline \multirow{4}{*}{$\begin{array}{l}\text { Mortality indicators: } \\
\text { Comparative mortality } \\
\text { figure } \\
\text { Ratio of potential years of } \\
\text { life lost } \\
\text { Life expectancy at birth }\end{array}$} & & & & \\
\hline & Death certificates & $1983-89$ & $M, F, T$ & - \\
\hline & Death certificates & 1983-89 & $\mathrm{M}, \mathrm{F}, \mathrm{T}$ & - \\
\hline & Death certificates & $1983-89$ & $M, F, T$ & Years \\
\hline
\end{tabular}

$\mathbf{M}=$ males $\mathbf{F}=$ females $; \mathbf{T}=$ total . totalled 112817 , and the number for each neighbourhood ranged from 152 to 8832 .

\section{SOCIOECONOMIC INDICATORS}

The socioeconomic indicators used for each of the neighbourhoods were as follows:

- Percentage of unemployment and illiteracy in the population aged 15 to 64 years;

- Mean of monthly telephone expenditure;

- Mean age of cars;

- Mean engine power of cars;

- Mean of rateable values of buildings and land.

All of these, except unemployment and illiteracy, were adjusted by the number of families living in the neighbourhood. The indicators used are described further in table 1 .

\section{HEALTH INDICATORS}

A comparative mortality figure (CMF) (an index which compares mortality, standardised by the direct method, for each of the 38 neighbourhoods with the rate for the city as a whole) was calculated for each neighbourhood, using the total population of Barcelona in 1986 as a reference $^{17}$ (the value of the CMF for the whole of the city was 100).

Potential years of life lost (PYLL) were also calculated for the age interval between 1 and 70 years as proposed by Romeder and McWhinnie. ${ }^{18}$ To compare neighbourhoods, the ratio of potential years of life lost (RPYLL) was calculated as an indicator of premature mortality. This ratio compares the PYLL for each neighbourhood with the PYLL that might be expected on the basis of mortality for the Barcelona population as a whole (indirect standardisation method), using as standard rates the specific rates by age and sex for the whole of Barcelona population in $1986^{19}$ (the value of the RPYLL for the whole of the city was 100).

Finally, life expectancy at birth was calculated using the life table method. ${ }^{20}$

\section{STATISTICS}

To choose measures of statistical correlation, distributions of social and health indicators were tested for normality with the KolmogorovSmirnoff test. None of the indicators used showed normal distributions, even after logarithmic transformation. Consequently, the non-parametric Spearman's rank correlation coefficient $^{21}$ was chosen.

In addition, although the indicators were not normally distributed, multiple linear regression models were used to ascertain whether social variables were acting independently of each other. Weighted multiple regression was modelled using the stepwise approach. The neighbourhood population size was used as the weight. The CMF was used as the dependent variable and all the socioeconomic indicators as independent variables. As an approximation to adjustment by age, the percentage of each neighbourhood population aged 65 and over was entered into the model. 
Table 2 Description of socioeconomic and mortality indicators in the neighbourhoods of Barcelona

\begin{tabular}{|c|c|c|c|c|c|c|c|c|c|c|c|c|c|c|c|}
\hline & \multicolumn{3}{|c|}{ Most favourable value } & \multicolumn{3}{|c|}{ Least favourable value } & \multicolumn{3}{|c|}{ Difference } & \multicolumn{3}{|l|}{ Ratio } & \multicolumn{3}{|c|}{ Median } \\
\hline & $M$ & $F$ & $T$ & $M$ & $F$ & $T$ & $M$ & $F$ & $T$ & $M$ & $F$ & $T$ & $M$ & $F$ & $T$ \\
\hline \multicolumn{16}{|c|}{ Socioeconomic indicators: } \\
\hline Unemployment & $9 \cdot 1$ & $17 \cdot 4$ & $12 \cdot 5$ & $33 \cdot 8$ & $44 \cdot 9$ & $36 \cdot 4$ & $24 \cdot 7$ & $27 \cdot 5$ & $23 \cdot 9$ & $3 \cdot 7$ & $2 \cdot 6$ & $2 \cdot 9$ & $18 \cdot 1$ & $26 \cdot 3$ & $20 \cdot 6$ \\
\hline Illiteracy & $0 \cdot 3$ & 0.5 & 0.4 & $9 \cdot 7$ & $11 \cdot 9$ & $10 \cdot 8$ & $9 \cdot 4$ & $11 \cdot 4$ & $10 \cdot 4$ & $32 \cdot 3$ & $23 \cdot 8$ & $27 \cdot 0$ & $1 \cdot 4$ & $2 \cdot 5$ & $2 \cdot 0$ \\
\hline $\begin{array}{l}\text { Telephone usage } \\
\text { Power of car }\end{array}$ & & & $\begin{array}{l}6833 \\
22 \cdot 1\end{array}$ & & & $\begin{array}{l}987 \\
6 \cdot 3\end{array}$ & & & $\begin{array}{l}-5846 \\
-15 \cdot 7\end{array}$ & & & $\begin{array}{l}0 \cdot 14 \\
0 \cdot 29\end{array}$ & & & $\begin{array}{l}2439 \cdot 5 \\
10 \cdot 4\end{array}$ \\
\hline Age of car & & & $8 \cdot 1$ & & & $12 \cdot 0$ & & & 3.9 & & & $\begin{array}{l}0.29 \\
1.49\end{array}$ & & & $\begin{array}{l}10 \cdot 4 \\
10 \cdot 0\end{array}$ \\
\hline $\begin{array}{l}\text { Rateable value } \\
\text { buildings }\end{array}$ & & & $4 \cdot 2$ & & & 0.6 & & & $-3 \cdot 6$ & & & $0 \cdot 14$ & & & $1 \cdot 3$ \\
\hline Rateable value land & & & $5 \cdot 6$ & & & $0 \cdot 3$ & & & $-5 \cdot 3$ & & & 0.06 & & & $1 \cdot 0$ \\
\hline \multicolumn{16}{|l|}{ Mortality indicators: } \\
\hline $\mathrm{CMF}$ & $84 \cdot 47$ & $85 \cdot 22$ & $87 \cdot 41$ & $152 \cdot 99$ & $157 \cdot 15$ & $152 \cdot 43$ & $68 \cdot 52$ & $71 \cdot 93$ & $65 \cdot 02$ & 1.81 & 1.84 & 1.74 & $96 \cdot 3$ & $98 \cdot 0$ & $97 \cdot 3$ \\
\hline RPYLL & $72 \cdot 75$ & 75.91 & $74 \cdot 94$ & $251 \cdot 35$ & $243 \cdot 22$ & $237 \cdot 31$ & $178 \cdot 60$ & $167 \cdot 31$ & $162 \cdot 37$ & 3.45 & $3 \cdot 20$ & $3 \cdot 17$ & $92 \cdot 5$ & $95 \cdot 7$ & $92 \cdot 7$ \\
\hline Life expectancy & $75 \cdot 32$ & $81 \cdot 51$ & $78 \cdot 64$ & $64 \cdot 77$ & $75 \cdot 04$ & 69.94 & $-10 \cdot 5$ & $5-6 \cdot 47$ & $-8 \cdot 70$ & 0.86 & 0.92 & 0.89 & $73 \cdot 6$ & $80 \cdot 1$ & $77 \cdot 2$ \\
\hline
\end{tabular}

Difference $=$ least favourable value - most favourable value; ratio = least favourable value/most favourable value; $\mathrm{CMF}=$ comparative mortality figure; $\mathrm{RPYLL}=$ ratio of potential years of life lost; $M=$ males; $F=$ females; $T=$ total.

\section{Results}

The CMF ranged from $87 \cdot 41-152.43$ in the 38 neighbourhoods and the RPYLL from $74.94-237.31$ in both sexes. Both the absolute difference and the ratio between the value for the neighbourhood with the lowest mortality and that with the highest mortality were wider when premature mortality was examined (the absolute differences were 65.02 for $\mathrm{CMF}$ and 162.37 for RPYLL, and the ratios were 1.74 for CMF and 3.17 for RPYLL). This result was also obtained when males and females were examined separately (table 2 ).

Life expectancy at birth ranged from $64 \cdot 77$ 75.32 years in men and $75.04-81.51$ in women (representing a difference between affluent and deprived neighbourhoods of 10.55 years for men and 6.47 years for women). Both the absolute difference and the ratio of most to least affluent neighbourhoods were greater in men (table 2).

Table 2 also shows the variations in socioeconomic indicators among neighbourhoods. Both unemployment and illiteracy were more frequent in women: there were important differences between the most and least affluent neighbourhoods. There were also large relative differences in average telephone use and average rateable value.

The neighbourhoods in which mortality and socioeconomic indicators showed the most deprivation were in the centre of Barcelona (the historic centre of the city) as well as in the newer neighbourhoods on the edge of the city (the neighbourhoods marked in the figure).

The correlations between mortality indicators and socioeconomic indicators are shown in table 3. As can be observed, all except one of these were high and statistically significant: the higher the rate of unemployment, the greater the amount of illiteracy, and the older the cars, the greater the CMF and the RPYLL, and the lower the life expectancy (negative correlations). Conversely, the higher the telephone use, the more powerful the cars, and the greater the rateable value, the lower the mortality (negative correlations) and the greater the life expectancy. These cor-

Table 3 Spearman correlation coefficients between socioeconomic and mortality indicators for males, females, and both sexes in the 38 neighbourhoods of Barcelona

\begin{tabular}{|c|c|c|c|c|c|c|c|c|c|}
\hline \multirow{3}{*}{$\begin{array}{l}\text { Socioeconomic } \\
\text { indicators }\end{array}$} & \multicolumn{9}{|c|}{ Mortality indicators } \\
\hline & \multicolumn{3}{|l|}{$C M F$} & \multicolumn{3}{|l|}{$R P Y L L$} & \multicolumn{3}{|c|}{ Life expectancy } \\
\hline & $M$ & $F$ & $T$ & $M$ & $F$ & $T$ & $M$ & $F$ & $T$ \\
\hline $\begin{array}{l}\text { Illiteracy } \\
\text { Unemployment } \\
\text { Telephone usage } \\
\text { Power of car } \\
\text { Age of car } \\
\text { Rateable value } \\
\text { buildings } \\
\text { Rateable value } \\
\text { land }\end{array}$ & $\begin{array}{r}0 \cdot 824^{* *} \\
0 \cdot 754^{* *} \\
-0 \cdot 647^{* *} \\
-0.581^{* *} \\
0 \cdot 606^{* *} \\
-0.655^{* *} \\
-0.650^{* *}\end{array}$ & $\begin{array}{c}0.750^{* *} \\
0.610^{* *} \\
-0.598^{* *} \\
-0.471^{*} \\
0.484^{*} \\
-0.538^{* *} \\
-0.590^{* *}\end{array}$ & $\begin{array}{r}0.859^{* *} \\
0.768^{* *} \\
-0.687^{* *} \\
-0.582^{* *} \\
0.592^{* *} \\
-0.641^{* *} \\
-0.690^{* *}\end{array}$ & $\begin{array}{c}0.591^{* *} \\
0.580^{* *} \\
-0 \cdot 482^{*} \\
-0.410^{*} \\
0.593^{* *} \\
-0.569^{* *} \\
\\
-0.377^{*}\end{array}$ & $\begin{array}{c}0.547^{* *} \\
0.404^{*} \\
-0.456^{*} \\
-0.369 \\
0.437^{*} \\
-0.456^{*} \\
-0.383^{*}\end{array}$ & $\begin{array}{r}0 \cdot 655^{* *} \\
0 \cdot 581^{* *} \\
-0.531^{* *} \\
-0 \cdot 466^{*} \\
0 \cdot 568^{* *} \\
-0 \cdot 574^{* *} \\
\\
-0.453^{*}\end{array}$ & $\begin{array}{r}-0.762^{* *} \\
-0.704^{* *} \\
0.585^{* *} \\
0.523^{* *} \\
-0.577^{* *} \\
0.612^{* *}\end{array}$ & $\begin{array}{c}-0.721^{* *} \\
-0.572^{* *} \\
0.603^{* *} \\
0.442^{*} \\
-0.513^{* *} \\
0.526^{* *}\end{array}$ & $\begin{array}{r}-0.820^{* *} \\
-0.725^{* *} \\
0.662^{* *} \\
0.549^{* *} \\
-0.605^{* *} \\
0.645^{* *}\end{array}$ \\
\hline \multicolumn{10}{|c|}{$\begin{array}{l}\text { CMF }=\text { comparative mortality figure; RPYLL }=\text { ratio of potential years of life lost; } M=\text { males; } F=\text { females; } T=\text { total. } \\
{ }^{*} p<0 \cdot 01 ;{ }^{* *} p<0 \cdot 001 .\end{array}$} \\
\hline \multicolumn{10}{|c|}{$\begin{array}{l}\text { Table } 4 \text { Spearman correlation coefficients between socioeconomic indicators for men and women in the neighbourhoods } \\
\text { of Barcelona }\end{array}$} \\
\hline & Illiteracy & Unem & ployment 1 & $\begin{array}{l}\text { Telephone } \\
\text { usage }\end{array}$ & Power of car & Age of $c a r$ & $\begin{array}{l}\text { Rateab } \\
\text { value } \\
\text { buildin }\end{array}$ & & $\begin{array}{l}\text { Rateable } \\
\text { value land }\end{array}$ \\
\hline $\begin{array}{l}\text { Illiteracy } \\
\text { Unemployment } \\
\text { Telephone usage } \\
\text { Power of car } \\
\text { Age of car } \\
\text { Rateable value } \\
\text { buildings } \\
\text { Rateable value } \\
\text { land }\end{array}$ & $1 \cdot 0^{* *}$ & \multicolumn{2}{|c|}{$\begin{array}{l}0 \cdot 959^{* *} \\
1 \cdot 0^{* *}\end{array}$} & $\begin{array}{l}-0.879^{* *} \\
-0.941^{* *} \\
1.0^{* *}\end{array}$ & $\begin{array}{l}-0 \cdot 673^{* *} \\
-0 \cdot 723^{* *} \\
0 \cdot 754^{* *} \\
1 \cdot 0^{* *}\end{array}$ & $\begin{array}{l}0.723^{*} \\
0.830^{*} \\
-0.852^{*} \\
-0.728^{*} \\
1.0^{* *}\end{array}$ & \multicolumn{2}{|c|}{$\begin{array}{c}-0 \cdot 748^{* *} \\
-0.811^{* *} \\
0.848^{* *} \\
0.821^{* *} \\
-0.922^{* *} \\
1 \cdot 0^{* *}\end{array}$} & $\begin{array}{r}-0.890^{* *} \\
-0.915^{* *} \\
0.926^{* *} \\
0.770^{* *} \\
-0.715^{* *} \\
0.758^{* *} \\
\\
1 \cdot 0^{* *}\end{array}$ \\
\hline
\end{tabular}


relations were higher in men than in women. For both sexes, all three mortality indicators showed the highest correlations with illiteracy (Spearman's correlation coefficient $=0.859$ for CMF, 0.655 for RPYLL, and -0.820 for life expectancy; $\mathrm{p}<0.001$ ), followed in magnitude by the correlation with unemployment (Spearman $=0.768$ for CMF, 0.581 for RPYLL, and -0.725 for life expectancy; $p<0.001$ ).

Both the mortality and socioeconomic indicators were highly intercorrelated: Pearson's correlation coefficient showed similar results. Of the socioeconomic indicators, illiteracy and unemployment showed the highest correlation (Spearman $=0.959, \mathrm{p}<0.001 ;$ Pearson $=0.941$, $\mathrm{p}<0.001$ ) (table 4). CMF was positively correlated with RPYLL, but both indicators were negatively correlated with life expectancy, with coefficients higher than $0.9(\mathrm{p}<0.001)$.

Stepwise multiple linear regression was performed with $\mathrm{CMF}$ as the dependent variable. Illiteracy and the percentage of the neighbourhood population aged $\geq 65$ were retained in the model $\left(R^{2}=0 \cdot 77, F\right.$ significance $=$ $0 \cdot 0000$; illiteracy slope coefficient $=4 \cdot 94$ ).

\section{Discussion}

Considerable differences in the CMF, RPYLL, and life expectancy were found for both men and women in the 38 districts of Barcelona. For RPYLL, a measure of premature death, both the differences between and ratios of the values of the most and least affluent neighbourhoods were wider. Several authors have already described how differences in mortality are greater when younger subpopulations are taken into account. ${ }^{6223}$

The differences in mortality indicators observed between neighbourhoods show a geographical distribution of the population related to social and economic factors. The correlations between the CMF, RPYLL, and life expectancy at birth and socioeconomic indicators indicate that the greater the disadvantage in terms of social and economic indicators, the worse the health indicators. The relationship between unemployment and mortality has been investigated extensively, both in ecological studies and studies based on individual data, and unemployment has been related to health inequalities, even independently of social class. ${ }^{5624-28}$

Illiteracy is an index of the standard of education while the amount of telephone usage and the power and age of cars are indirect measures of income. The rateable value represents the value of the buildings (including residential and commercial property) and the value of land, which have not always been related with income. ${ }^{29}$ Other studies have used the fact of having a car or not as an indicator of income. Carstairs and Morris ${ }^{6}$ and Townsend ${ }^{5}$ used this to construct their poverty indices and found a relationship between the fact of not having a car and the existence of a high mortality rate. Other authors have also used it as an indirect indicator of socioeconomic level. ${ }^{30}$ We had the average car statistics (engine power and age) for all neighbourhoods, variables which are correlated with the other indicators and which may also provide a good indication of poverty or affluence.

We used both positive (life expectancy) and negative (premature death) measures, that have not been used frequently in health inequalities research. Life expectancy is especially important as an overall measure of population health and development, and the measure of premature death (RPYLL) is regarded as an approach to quantifying avoidable mortality in the population.

The most relevant finding is the strong correlation between health indicators and illiteracy - this was even stronger than the correlation found between unemployment rates and mortality. Although ecological data have been used and potential bias (ecological fallacy) does exist, illiteracy is a variable which, at the individual level, is usually determined early in life and does not change thereafter. On the other hand, unemployment and income are not such stable concepts at the individual level, since these can vary through an individual's lifetime. Moreover, the high correlations found in illiteracy, unemployment, and income indicators probably reflect different and partial approaches to the definition of socioeconomic level. Furthermore, using illiteracy or the level of education to classify people into socioeconomic levels has the advantage of yielding a value for each adult, whereas occupation is useful only for employed people, and has the added drawback of using the occupation based social class of the husband for married women. Given the stronger correlation found in our study between illiteracy and mortality indicators compared with the other socioeconomic indicators, and the fact that illiteracy does not usually change over time, we conclude that illiteracy is a good indicator to use in ecological studies of health and social class.

The level of education and duration of schooling are indicators that have been related to health inequalities, and it is always found that the shorter the period of schooling the poorer the health. ${ }^{93132}$ Kitagawa described how lower mortality was associated with more years of education in the United States. ${ }^{33}$ Rogot et al found important differences in life expectancy according to the level of education, as well as to family income and occupation. In their study, the lower the socioeconomic level, the lower the life expectancy. ${ }^{34}$

Several studies have been carried out in cities in the UK, The Netherlands, and the USA showing that there are important inequalities between different districts. Townsend et al describe the inequalities found in Bristol. ${ }^{35}$ They related mortality and morbidity indicators (deaths between 15 and 64 years, deaths over 65 years, stillborn and infant mortality, low birth weight) to socioeconomic indicators (households with fewer rooms than persons, households with no car, economically active persons seeking work, children receiving free school meals, households experiencing disconnection of electricity).$^{35} \mathrm{~A}$ study carried out in Rotterdam also found a relationship between 
the standardised mortality ratio and socioeconomic indicators (unemployment, persons receiving benefit, 17-18 year olds still in education, and income level) at a neighbourhood level. ${ }^{36}$ Dayal et al described the variations in nine causes of mortality in the city of Philadelphia and related these to a socioeconomic score. They found that the neighbourhoods with a higher mortality (which were central neighbourhoods with a predominantly black population) were those with the lowest socioeconomic scores. ${ }^{37}$

In Spain, there have been studies on health inequalities associated with socioeconomic factors in towns that have related standardised mortality rates and PYLL to composite socioeconomic indicators. ${ }^{3839}$ In the city of Barcelona, preliminary studies found differences in mortality between the most deprived neighbourhoods and the rest of the city. ${ }^{40-42}$ Our research group found a correlation between a composite health and deprivation index, similar to that proposed by Townsend et al, at neighbourhood level in Barcelona and Valencia. ${ }^{43}$ No previous research has been undertaken in either Barcelona or in Spain that relates life expectancy and RPYLL to the socioeconomic indicators used in the present study.

We have used both direct and indirect standardisation to calculate the CMF and RPYLL, respectively. The indicators standardised by the indirect method are not strictly comparable between two neighbourhoods; however, direct and indirect standardisation give different results only if the three assumptions proposed by Silcock are violated (population structures of the neighbourhoods must differ, the variation of mortality with age must differ, and both differences must be strongly correlated). ${ }^{44}$ In this study the three assumptions were not violated and, moreover, the CMF and SMR for each neighbourhood showed very similar results. ${ }^{45}$

Unemployment and illiteracy were greater in women and large differences were seen between the various neighbourhoods. These indicators are not standardised by age, and although age limits have been used when measuring them ( 15 and 64 years), age may be a confounding factor, since both unemployment and illiteracy vary according to age group. However, the percentage of the population aged $\geq 65$ was entered into the weighted multiple regression model as an approach to age adjustment. It must be pointed out that only illiteracy and the percentage of the neighbourhood population aged $\geq 65$ were entered into the regression model, and not the other variables; this was probably because of the low tolerance and high correlations that exist in the socioeconomic indicators.

The socioeconomic indicators used in this study are those available at neighbourhood level. It would have been interesting to have included other indicators such as occupation or level of income but these data were not available. Furthermore, it is very difficult in Spain to study individual mortality data in relation to social class since most death certificates do not mention the deceased's oc- cupation, ${ }^{46}$ and mortality and census data cannot be linked. ${ }^{47}$

The other indicators used in this study (the age and power of cars, telephone use, and rateable value) are indirect indicators of the level of income and have not been used in previous research. However, all are highly correlated with each other, which indicates that they are all measuring the same phenomenon. In order to study inequalities in women, it would be interesting to have more specific data, since the indicators used often reflect better the socioeconomic level of men. ${ }^{48}$

The neighbourhoods studied are administrative areas, and hence not homogenous in themselves. Furthermore, they are small areas, which means that the variability of some mortality indicators may be considerable, even after having aggregated seven years. ${ }^{49}$ It would have been interesting therefore to have studied other indicators related with health inequalities such as infant and perinatal mortality ${ }^{50} 52$ but the low number of deaths in these age groups, even aggregating seven years, would show such wide variability that results could be unreliable.

In the future, it would be interesting to study inequalities in more homogenous areas, as well as to look more closely at the various causes of death, and especially at the causes of avoidable death, the study of which could be useful as a criterion for the distribution of health care services and for the development of intersectoral-coordinated actions.

This study has detected significant correlations of illiteracy, unemployment, and income levels with life expectancy, premature death rates (RPYLL), and CMF in the city of Barcelona. Although it is important to develop further research on health inequalities, this evidence is already sufficient to enable the formulation of strategies directed at reducing inequalities.

We are indebted to Dr Vera Carstairs for the support and advice which she has given to us from the beginning of this project, as well as for her comments on previous versions of this paper. as well as for her comments on previous versions of this paper.
We are also very grateful to Dr Louis Lemkow for his valuable We are also very grateful to Dr Louis Lemkow

This study was supported by Fondo de Investigaciones SanThis study was supp
itarias $(90 \mathrm{E} / 0497)$.

1 Department of Health and Social Security. Report of the resource allocation working party. London: DHSS, 1976.

2 Townsend P, Davidson N. The Black report. In: Townsend P, Davidson N, Whitehead M. Inequalities in health: the Black report and the health divide. London: Penguin Books, Black
1988.

3 Marmot MG, Kogevinas M, Elston MA. Social/economic status and disease. Ann Rev Public Health 1987;8:111-35.

4 Fox AJ. Socio-economic differences in mortality and morbidity. Scand F Soc Med 1990;18:1-8.

5 Townsend P, Phillimore P, Beattie A. Health and deprivation. Inequality and the north. London: Routledge, 1988.

6 Carstairs V, Morris R. Deprivation and health in Scotland. Aberdeen: Aberdeen University Press, 1991

7 Whitehead M. The health divide. In: Townsend P, Davidson $\mathrm{N}$, Whitehead M. Inequalities in health: the Black report and the health divide. London: Penguin Books, 1988.

8 World Health Organization. Targets for health for all. Copenhagen: WHO, 1985.

9 Valkonen T. Problems in the measurement and international comparison of socio-economic differences in mortality. Soc Sci Med 1993;36:409-18.

10 Carstairs V, Morris R. Deprivation and mortality: an alternative to social class? Community Med 1988;11:210-19. 1 McCord C, Freeman HP. Excess mortality in Harlem. $N$ Engl f Med 1990;322:173-7.

12 Carr JA, Di Rocco A. Excess mortality in Harlem (letter). N Engl f Med 1990;322:1606.

13 Liebman J, Axler F, Kotranski L, Steinberg-Scribner S. Excess mortality in Harlem (letter). $N$ Engl f Med 1990; 322: 1606-7.

14 Ramis-Juan O, Sokov V. Social health inequalities in south 
European countries: it is a different problem? In: Fox J ed. Health inequalities in European countries. Aldershot: Gower, 1989.

15 Sampere E, Soler J, Ferrando P. L'evolució dels indicador socials a Barcelona: 1981-1986. Vol I. Caracteristiques principals. Barcelona: Area de Serveis Socials. Ajuntament de Barcelona, 1988.

16 Index de capacitat economica familiar. Barcelona: Ajuntament de Barcelona i Caixa d'Estalvis i Pensions de Barcelona 1991

17 Breslow NE, Day NE. Statistical methods in cancer research. Vol II: The design and analysis of cohort studies. Lyon: International Agency for Research on Cancer, 1987:61-4.

18 Romeder JM, McWhinnie JR. Potential years of life lost between ages 1 and 70: an indicator of premature mortality for health planning. Int $\mathcal{f}$ Epidemiol 1977;6:143-51.

19 Kleinman JC. Age-adjusted mortality indexes for small areas: applications to health planning. Am $\mathcal{F}$ Public Health $1977 \cdot 67 \cdot 834-40$.

20 Shryock HS, Siegel JS. The methods and materials of demography. New York: Academic Press, 1976.

21 Armitage P. Statistical methods in medical research. Oxford: Blackwell Scientific Publications, 1983:403-6.

22 Hume D, Womersley J. Analysis of death rates in the population aged 60 years and over of Greater Glasgow by postcode sector of residence. 7 Epidemiol Community Health 1985;39:357-63.

23 Blane D, Smith GD, Bartley M. Social class differences in years of potential life lost: size, trends and principal causes. BMF 1990;30:429-32.

24 Moser KA, Fox AJ, Jones DR. Unemployment and mortality in the OPCS longitudinal study. Lancet 1984;ii:1324-8.

25 Moser KA, Fox AJ, Jones DR, Goldblatt PO. Unemployment and mortality: further evidence from the
OPCS longitudinal study $1971-81$. Lancet $1986 ; 1: 365-7$.

26 Iversen L, Andersen O, Andersen PK, Christoffersen K, Keiding N. Unemployment and mortality in Denmark, 1970 80. BMF 1987;295:879-84.

27 Martikainen PT. Unemployment and mortality among Finnish Men, 1981-5. BMF 1990;301:407-11

28 Klein-Hesselink DJ, Spruit I. The contribution of unemployment to socioeconomic health differences. Int $f$ Epidemiol 1992;21:329-37.

29 Liberatos P, Link BG, Kelsey JL. The measurement of social class in epidemiology. Epidemiol Rev 1988;10:87-121.

30 Smith GD, Shipley MJ, Rose G. Magnitude and causes of socioeconomic differentials in mortality: further evidence
from the Whitehall study. $\mathcal{F}$ Epidemiol Community Health from the Whitehall

31 Valkonen T. Adult mortality and level of education: a comparison of six countries. In: Fox J. Health inequalities in European countries. Aldershot: Gower, 1989.

32 Kunst AE, Mackenbach JP. The size of mortality differences associated with educational level in nine industrialized countries. Am f Public Health 1994;84:932-7.

33 Kitagawa EM, Hauser PM. Differential mortality in the United States: a study in socioeconomic epidemiology. Cambridge, MA: Harvard University Press, 1973.
34 Rogot E, Sorlie PD, Johnson NJ. Life expectancy by employment status, income and education in the longitudinal ployment status, income and education in the longitudina

35 Townsend P, Simpson D, Tibbs N. Inequalities in health in the city of Bristol: a preliminary review of statistical evidence. Int f Health Services 1985;15(4):637-63.

36 Van Oers JAM, Teeuwen JHM. Socio-economic status and differences in mortality between Rotterdam neighbourhoods. Tjdschrift Sociale Gezondheidszorg 1991;69:55 60.

37 Dayal H, Goldberg-Alberts R, Kinman J, Ramos J, Sharrar R, Shapiro S. Patterns of mortality from selected causes in an urban population. Fournal of Chronic Diseases 1986; 39(11):877-88.

38 Casi A, Moreno C. Desigualdad ante la muerte: estudio comparativo entre comunidades de Navarra en el segmento de población de 25 a 74 años. Atención Primaria 1992;10(1):543-8.

39 Martín FJ, March JC. Desigualdades sociales en salud en la ciudad de Málaga. Gac Sanit 1992;32:198-206.

40 Alonso J, Antó JM. Desigualdades de salud en Barcelona. Gac Sanit 1988;2:4-12.

41 Costa J. Desigualtats en la mortalitat als barris de Barcelona: la seva relació amb l'atur, l'analfabetisme i la categoria professional. Barcelona: Universitat Autònoma de Barcelona, 1989. (Dissertation.)

42 Borrell $\mathrm{C}$, Plasència A, Pañella $\mathrm{H}$. Excés de mortalitat en una àrea urbana cèntrica: el cas de Ciutat Vella a Barcelona. Gac Sanit 1991;5:243-53.

43 Arias A, Rebagliato M, Palumbo MA, et al. Desigualdades de salud en Barcelona y Valencia. Med Clin (Barc) 1993; 100:281-7.

44 Silcock $H$. The comparison of occupational mortality rates. Popul Stud 1959;13:183-92.

45 Borrell C, Arias A, Tristán M. Mortalitat agregada a la ciutat de Barcelona (1983-1989). Análisi per barris municipals. Sèrie estadistiques de salut. Barcelona: Ajuntament de Barcelona, 1992.

46 Gispert $\mathrm{R}$. La variable profesión en las estadistiques de mortalidad. Gac Sanit 1989;11:371-6.

47 Regidor E, Gutiérrez-Fisac JL, Rodriguez C. Diferencias y desigualdades en salud en España. Madrid: Diaz de Santos, 1994

48 Krieger N. Women and social class: a methodological study comparing individual, household, and census measures as predictors of black/white differences in reproductive as predictors of black/white differences in reproductive
history. $₹$ Epidemiol Community Health 1991:45:35-42

49 Carstairs V. Small area analysis and health services research Community Med 1981;3:131-9.

50 Wise PH, Kotelchuck M, Wilson ML, Mills M. Racial and socioeconomic disparities in childhood mortality in Boston. N Engl f Med 1985;313:360-6.

51 Forbes JF, Boddy FA, Pickering R, Wyllie M. Perinata mortality in Scotland: 1970-9. F Epidemiol Community Health 1989;43:280-4.

52 Tresserras R, Canela J, Alvarez J, Sentís J, Salleras L. Infant mortality, per capita income, and adult illiteracy: an ecological approach. Am f Public Health 1992;82:435-7. 